Article

\title{
Sustainable Food Production and Nutraceutical Applications from Qatar Desert Chlorella sp. (Chlorophyceae)
}

\author{
Rihab Rasheed, Imen Saadaoui * , Touria Bounnit, Maroua Cherif, Ghamza Al Ghazal and \\ Hareb Al Jabri \\ Algal Technologies Program, Centre for Sustainable Development, Qatar University, P.O. Box 2713 Doha, Qatar; \\ rihabrasheed@qu.edu.qa (R.R.); touria.bounnit@qu.edu.qa (T.B.); cherif.maroua@qu.edu.qa (M.C.); \\ ali88@qu.edu.qa (G.A.G.); h.aljabri@qu.edu.qa (H.A.J.) \\ * Correspondence: imen.saadaoui@qu.edu.qa; Tel.: +974-4403-3907
}

Received: 6 May 2020; Accepted: 27 June 2020; Published: 13 August 2020

check for updates

Simple Summary: The world population is increasing rapidly, putting pressure on the existing resources, especially in the food sector. Besides having a continuous supply of food, it is also important to identify food sources that are nutritionally beneficial to the health of animals, fish, and humans. Hence, a balanced feed supplement including all the essential nutrients, such as amino acids, omega fatty acids, sugars, and carotenoids, is required. In this context, we have studied the beneficial effects of using a microalga, Chlorella sp. isolated from the desert environment in Qatar, as a potential feed supplement. We found that the local strain showed a rich biochemical profile, with high amounts of proteins and lipids having biomolecules essential for human. Furthermore, the hexane extracts of this strain showed high antiproliferative activity against leukemia, one of the deadliest cancers in the world, proving its potential in the path of drug discovery against cancers. Our research findings thus highlight the nutraceutical potential of the local Chlorella sp., which can resist high temperatures of up to $40^{\circ} \mathrm{C}$, making it suitable for a large-scale production in ponds, year-round, for use as a sustainable food supplement.

\begin{abstract}
Microalgae isolated from the Qatari desert was identified as thermotolerant, with a rich metabolite profile that is appropriate for use as food and health supplements. In this research, a species of Chlorella, QUCCCM3, from the Qatar University Culture Collection of Cyanobacteria and Microalgae, was investigated for its growth characteristics and metabolite compositions for use as potential feedstock for food production. The strain was cultivated at 30,35 , and $40^{\circ} \mathrm{C}$, covering the annual average low and high temperatures in Qatar. The highest growth rates were recorded for cultures at $30^{\circ} \mathrm{C}$ with $0.64 \pm 0.04$ day $^{-1}$, followed by a growth rate of $0.54 \pm 0.06$ day $^{-1}$ at $40{ }^{\circ} \mathrm{C}$, indicating its thermotolerance ability. The biomass exhibited a high protein content $(43 \pm 2.3 \%)$, with existence of lysine ( $4.13 \%$ ) as an essential amino acid, and docosahexaenoic acid, linoleic acid, and alpha-linolenic acid as important omega fatty acids present. On the other hand, Chlorella sp. QUCCCM3 also exhibited a high capacity for scavenging free radicals with an antiproliferative effect against chronic myeloid leukemia K562 cancer cells. The results indicate that Chlorella sp. QUCCCM3 is a promising candidate that can be produced year-round, in the Qatar environment, for commercial applications such as feed and nutraceutical supplements.
\end{abstract}

Keywords: biomolecules; food; Chlorella; proteins; PUFAs; thermotolerance 


\section{Introduction}

Microalgae biomass is highlighted as a promising resource for different applications. Energy industries are exploring their potential as biodiesel, bioethanol, and biogas [1]. However, the economic feasibility of these processes remains questionable [2]. It is the nutrition sector that is ideally utilizing these organisms as potential food and feed sources.

Microalgae are mini factories, synthesizing important metabolites, such as proteins, carbohydrates lipids, essential amino acids, carotenoids, polyunsaturated fatty acids, and essential vitamins. These biological components are gaining importance as sustainable sources of feed, to satisfy the nutritional demands of a growing population [3-5]. The ever-increasing demand for animal proteins has put tremendous pressure on the existing resources of poultry, cattle, and fish. Alternately, the high protein content in microalgae has favored their usage as feed [6]. In addition, the ability of microalgae to produce all essential amino acids is an added highlight in the quality of these proteins. It has been proved earlier that the quality of such proteins is much higher than conventional plant, milk, and soy proteins [3]. Carbohydrates are also an important class of metabolites in microalgae. Carbohydrates constitute a large proportion of the diets mainly used to feed cattle and livestock. They are known to provide the energy required for the animals and the microbes in their rumen, which is necessary to maintain a healthy gastrointestinal tract. Microalgae also synthesize a wide range of essential fatty acids that have a positive impact on the health of animals. Being primary producers of these fatty acids emphasizes the importance of enriching the animal feed by using such microalgae. The most important polyunsaturated fatty acids (PUFAs) comprise docosahexaenoic acid (DHA, 22:6, n-3), eicosapentaenoic acid (EPA, 20:5, n-3), arachidonic acid (ARA, 20:4, n-6), and $\alpha$-linolenic acids (ALA, 18:3, n-3). All of these fatty acids show multiple health benefits, uncluding in the treatment of cardiovascular disease and development of brain cells [7].

Microalgae are already known to support all the growth stages for marine and land animals [5]. When microalgae are added to the diets of domestic livestock, they confer numerous health benefits, such as improving immune response and disease resistance, promoting growth, enhancing milk production, increasing quality of meat and eggs, and antiviral and antibacterial activities [8]. Previous research work done on poultry highlighted that incorporating up to $15 \%$ algae in poultry rations is beneficial for their growth, with no adverse effects on their health. Eggs fortified with DHA via selective feeding of hens are already popular in markets [9-12]. Moreover, microalgae are commonly used in aquaculture, since they play a foundational role in the aquatic food chain, and they are easily ingested and assimilated by fishes and gastropods [13]. Fish fed with up to 10\% algae exhibit enhanced growth and development [14]. Microalgal biomass rich in carbohydrates is an optimal source of energy for juvenile oysters and a few larval stages, including in Patinopecten yessoensis (Jay) scallop larvae [3,12].

Besides nutritional benefits, microalgae also have high potential for pharmaceutical applications. This is due to the antioxidant properties of PUFAs and another class of secondary metabolites, such as carotenoids, found in microalgae. Omega-3 fatty acids and carotenoids are known for their health benefits in cases related to cancer and cardiovascular diseases [15]. The combined effects of nutritional and pharmaceutical benefits of microalgae contribute to their nutraceutical aspect as feed.

The common species of algae used as food supplements include Arthrospira sp., Dunaliella salina, Chlorella sp., and Tetraselmis sp. [16]. Among them, freshwater strains, such as Chlorella sp., are known to produce high amounts of proteins and other molecules with antioxidant properties, such as omega-3 and omega- 6 fatty acids $[17,18]$. Several studies have shown that Chlorella biomass has a positive influence on the animals when used as feed, due to its biochemical composition, palatability, and higher digestibility of nutrients. Similar positive impacts were recorded in aquaculture when the biomass was used as feed. These factors have favored their economical use as potential animal-feed constituents [19].

Qatar is a peninsula that is governed by a hot and humid climate for most of the year. Food security and self-sufficiency in food products is of prime importance in the country. In our current research, a Chlorella sp. QUCCCM3, isolated from the local desert environment, was evaluated for its thermotolerance capacity, biomass productivity, metabolites content, antioxidant capacity, 
and antiproliferative properties. The strain was thus characterized to determine its suitability as feed component, to improve the health and nutritional value of the animals.

\section{Materials and Methods}

\subsection{Morphological Characterization Chlorella sp. QUCCCM3}

Chlorella sp. QUCCCM3, a freshwater microalgae, isolated from Qatar's Desert environment, belonging to the Qatar Culture Collection of Cyanobacteria and Microalgae [20] was selected for the present study. The morphology of Chlorella sp. QUCCCM3 was studied by using light microscopy (Primo star HAL microscope, full Kohler, Carl Zeiss, Germany), under 100× magnification. The strain was observed for its features, under two different abiotic stress, namely (i) continuous light and (ii) high temperature $\left(40{ }^{\circ} \mathrm{C}\right)$. Culture at $30^{\circ} \mathrm{C}$ and a photon flux density of $200 \mu \mathrm{mol}$ photons $\mathrm{m}^{-2} \mathrm{~s}^{-1}$ with 12:12 dark: light cycles were used as control.

\subsection{Microalgae Cultivation and Growth Analysis}

Chlorella sp. QUCCCM3 was cultivated by using BG11 freshwater growth medium. The composition of the medium was as follows: $\mathrm{NaNO}_{3}\left(1500 \mathrm{mg} \mathrm{L}{ }^{-1}\right), \mathrm{K}_{2} \mathrm{HPO}_{4} \cdot 3 \mathrm{H}_{2} \mathrm{O}\left(40 \mathrm{mg} \mathrm{L}^{-1}\right), \mathrm{MgSO}_{4} \cdot 7 \mathrm{H}_{2} \mathrm{O}$ (75 mg L $\left.\mathrm{mg}^{-1}\right), \mathrm{CaCl}_{2} \cdot 2 \mathrm{H}_{2} \mathrm{O}\left(36 \mathrm{mg} \mathrm{L}^{-1}\right), \mathrm{Na}_{2} \mathrm{CO}_{3}\left(20 \mathrm{mg} \mathrm{L}^{-1}\right)$, citric acid $\left(6 \mathrm{mg} \mathrm{L}^{-1}\right)$, Ferric ammonium citrate $\left(6 \mathrm{mg} \mathrm{L}^{-1}\right)$, EDTA $\left(1 \mathrm{mg} \mathrm{L}^{-1}\right), \mathrm{H}_{3} \mathrm{BO}_{3}\left(2.86 \mathrm{mg} \mathrm{L}^{-1}\right), \mathrm{MnCl}_{2} \cdot \mathrm{H}_{2} \mathrm{O}\left(1.81 \mathrm{mg} \mathrm{L}^{-1}\right), \mathrm{ZnSO}_{4} \cdot 7 \mathrm{H}_{2} \mathrm{O}$ $\left(0.222 \mathrm{mg} \mathrm{L}^{-1}\right), \mathrm{CuSO}_{4} \cdot 5 \mathrm{H}_{2} \mathrm{O}\left(0.079 \mathrm{mg} \mathrm{L}^{-1}\right), \mathrm{Na}_{2} \mathrm{MoO}_{4} \cdot 2 \mathrm{H}_{2} \mathrm{O}\left(0.390 \mathrm{mg} \mathrm{L}^{-1}\right)$, and $\mathrm{Co}\left(\mathrm{NO}_{3}\right)_{2} \cdot 6 \mathrm{H}_{2} \mathrm{O}$ $\left(0.049 \mathrm{mg} \mathrm{L}^{-1}\right)$ [21,22]. All components were obtained from Sigma-Aldrich, for research use.

A single colony of Chlorella sp. QUCCCM3 was used to inoculate $5 \mathrm{~mL}$ of BG11 liquid media, which was incubated for 7 days at $30^{\circ} \mathrm{C}$, under an agitation of $200 \mathrm{rpm}$ and a photon flux density of $200 \mu \mathrm{mol}$ photons $\mathrm{m}^{-2} \mathrm{~s}^{-1}$, in an illuminated shaker (Innova ${ }^{\circledR} 44 \mathrm{R}$ incubator shaker, New Brunswick Scientific, Ocala, FL, USA). The culture was gradually scaled up to a volume of $500 \mathrm{~mL}$ and incubated under the previously mentioned conditions of growth, with an initial optical density at $750 \mathrm{~nm}\left(\mathrm{OD}_{750 \mathrm{~nm}}\right)$ of 0.2 . A daily assessment of the $\mathrm{OD}_{750 \mathrm{~nm}}$ was performed, using a spectrophotometer (Jenway 73100 , Staffordshire, UK), for which $1 \mathrm{~mL}$ of the culture was taken and measured against a blank of only media without the cells. All cultures were done in duplicate, with two flasks, in the same experiment. The culture was harvested after 12 days of cultivation, at the onset of the stationary phase. The biomass was harvested and then freeze-dried prior to being subjected to assessment of its metabolite content.

Dry weight was determined in replicates [23], for which $10 \mathrm{~mL}$ aliquots were collected and filtered through $0.47 \mathrm{~mm}$ cellulose nitrate membrane filter (Whatman, Darmstadt, Germany). Filters were dried at $80^{\circ} \mathrm{C}$ for $24 \mathrm{~h}$, and then transferred to desiccators over silica gel, for dehydration, until stable weight was recorded.

The growth rate $(\mu)$ was determined by using the following formula [24]:

$$
\mu=\frac{\ln N_{2}-\ln N_{1}}{T_{2}-T_{1}}
$$

where $T_{1}$ is the time corresponding to the beginning of the exponential phase; $T_{2}$ is the time corresponding to the end of the exponential phase; $N_{1}$ is $\mathrm{OD}_{750 \mathrm{~nm}}$ at $T_{1}$; and $N_{2}$ is $\mathrm{OD}_{750 \mathrm{~nm}}$ at $T_{2}$.

Biomass productivities were calculated based on biomass dry weight, using the following formula [25]:

$$
P=\left(X_{2}-X_{1}\right) /\left(T_{2}-T_{1}\right)
$$

where $X_{2}$ is biomass concentrations $\left(\mathrm{g} \mathrm{L}^{-1}\right)$ at $\mathrm{T}_{\text {end }}$ (end point of culture), and $X_{1}$ is the biomass concentration $\left(\mathrm{g} \mathrm{L}^{-1}\right)$ at $\mathrm{T}_{\text {initial }}$ (start point of cultivation). All measurements were performed in triplicates. 


\subsection{Thermotolerance Study}

For the study of the thermotolerance capacity, Chlorella sp. QUCCCM3 was scaled up gradually, as previously described (Section 2.2), to $1 \mathrm{~L}$ in bioreactors (DASGIP parallel bioreactor system, Eppendorf Inc., Ocala, FL, USA), with an initial $\mathrm{OD}_{750 \mathrm{~nm}}$ of 0.2 . The strain was subjected to four culture temperatures, nameley $30,35,40$, and $45^{\circ} \mathrm{C}$, with a mixing set to $200 \mathrm{rpm}$, using a pitch blade impeller. The illumination was provided by 3 internal DASGIP LED sticks having 3 channel emission spectrum (channel A, 660,780 nm; channel B, 572,625,640 nm; channel C, $453 \mathrm{~nm}$ ). Set points were 2.00, 1.244, and $2.00 \mu \mathrm{mol}$ photons.s -1 for channels $\mathrm{A}, \mathrm{B}$, and C, respectively, fixed for a photon flux density of approximately $200 \mu \mathrm{mol}$ photons $\mathrm{m}^{-2} \mathrm{~s}^{-1}$, which is considered to be optimum for the standard cultivation of microalgae, at $12 \mathrm{~h}: 12 \mathrm{~h}$ dark:light cycles. A daily assessment of the $\mathrm{OD}_{750 \mathrm{~nm}}$ was performed to be able to compare the growth performance of the strain under the different temperatures tested.

\subsection{Metabolite Extraction and Estimation}

The microalgal biomass collected after 12 days of cultivation, corresponding to the end of exponential phase of culture, was washed with deionized water and freeze-dried (Labconco, Freezone, Kansas city, MO, USA) prior to being subjected for metabolite analysis. For total protein, $25 \mathrm{mg}$ of dried microalgae was hydrolyzed overnight at $60^{\circ} \mathrm{C}$, using $5 \mathrm{~mL}$ sodium hydroxide $(\mathrm{NaOH} 0.1 \mathrm{M})$ from Sigma-Aldrich (St. Louis, MO, USA) [26]. The total protein content was determined for the supernatant by using colorimetric assay, using Folin ciocalteau reagent [27].

Total lipids were extracted from freeze-dried algae biomass, using the method of Folch, with some modifications, where freeze-dried biomass was treated with sodium chloride solution $(0.88 \%)$ and incubated at $4{ }^{\circ} \mathrm{C}$, in an adequate volume of methanol. Post overnight incubation, double the volume of chloroform (Analytical grade; Sigma-Aldrich, St. Louis, MO, USA) was added to the mixture, and cells were disrupted by tissue lyzer (Qiagen, Hilden Germany). The mixture was centrifuged at $5000 \times g$ for $5 \mathrm{~min}$, and supernatant was transferred into a pre-weighed tube. The methanol chloroform extraction step was repeated to ensure complete removal of lipids from the biomass. The organic phase was separated from the aqueous phase by adding $0.88 \%$ of $\mathrm{NaCl}$ and mixing of the solution. The organic phase was collected, dried, and weighed, and the lipid content was measured gravimetrically [28,29]. The lipid content was calculated by using the following equation [30].

$$
\text { Lipid content }(\%)=\text { Total lipids } \frac{g}{\text { Dry }} \text { biomass }(g) \times 100
$$

Carbohydrates were estimated using by phenol sulphuric acid reagent [31]. For the extraction, freeze-dried biomass was dispersed in glacial acetic acid and incubated at $85^{\circ} \mathrm{C}$ for $20 \mathrm{~min}$, to remove all chlorophyll that can interfere with the colorimetric assay. The colorless pellet obtained after treatment was hydrolyzed, using hydrochloric acid $(\mathrm{HCl} 4 \mathrm{M})$, at $90^{\circ} \mathrm{C}$ for $2 \mathrm{~h}$. Finally, the supernatant was neutralized with water and subjected to calorimetric assay, using phenol sulphuric acid.

\subsection{Amino Acid Profiling}

Amino acids were quantified by using pre-column derivatization with O-phtalaldehyde (OPA) and 9-fluorenylmethyl chloroformate (FMOC) after methods as described in Reference [32]. Pre-weighed algal biomass (approximately $2 \mathrm{mg}$ ) was hydrolyzed in $100 \mu \mathrm{L} 6 \mathrm{~N} \mathrm{HCl}$ at $120{ }^{\circ} \mathrm{C}$ for $24 \mathrm{~h}$ [33]. Analysis was performed in replicate, dried, and resuspended in $100 \mu \mathrm{L} 0.1 \mathrm{~N} \mathrm{HCl}$. A reaction blank (no biomass) and a known protein standard (bovine serum albuminc; Sigma\# 1076192) were performed. The HPLC system (Agilent 1260, Santa Clara, CA, USA) included a programmable autosampler for fully automated sample handling, derivatization, and sample injection $(30 \mu \mathrm{L})$. Amino acid derivatives were separated by reverse-phase high-performance liquid chromatography (RP-HPLC), using a $5 \mu \mathrm{m}$ Hypersil amino acid-octadecyl silane column (AA-ODS; $2.1 \times 200 \mathrm{~mm}$, Thermo Fisher Scientific, Waltham, MA, USA), using the solvent system and gradient described by 
Zheng et al. [34]. Amino acids derivatives were detected by using a variable wavelength UV detector (Agilent 1260, Santa Clara, CA, USA) and an in-line fluorescence detector (Agilent 1260, Santa Clara, CA, USA). The sample was quantified against a 5-point calibration curve from dilutions prepared from a standardized mixture of L-amino acids (Sigma Aldrich \# P0834, St. Louis, MO, USA). Sixteen amino acids were reported; due to deamination, asparagine and glutamine were reported with aspartate and glutamate, respectively, as ASX and GLX. Note that tryptophan cannot be not determined by this method. The system operations and data analysis were performed on Chemstation. The assay was capable of detecting amino acid derivatives between 1 and $100 \mathrm{nmol}$.

\subsection{Fatty Acid Methyl Ester (FAME) Profiling}

FAMEs were extracted via a one-step transesterification method, where a known amount of freeze-dried biomass was treated, using sulfuric acid (95\%; analytical grade from Sigma-Aldrich) and methanol solution $\left(\mathrm{H}_{2} \mathrm{SO}_{4}: \mathrm{CH}_{3} \mathrm{OH}=1: 10\right)$, and sonicated for $10 \mathrm{~min}$. This step was followed by heat treatment at $80{ }^{\circ} \mathrm{C}$ for $2 \mathrm{~h}$. Further, the mixture was transferred to a tube containing $1 \mathrm{~mL}$ of distilled water and $3 \mathrm{~mL}$ of hexane: chloroform (4:1; hexane and chloroform from Sigma-Aldrich, St. Louis, MO, USA) mixture and centrifuged. The top layer containing FAME fractions was filtered and analyzed, using GD-FID (Shimadzu 2010 plus, Kyoto, Japan) [29]. Then, $2 \mu \mathrm{L}$ of sample was injected into gas chromatography set at $100-240^{\circ} \mathrm{C} / 5 \mathrm{~min}$ holding time. The sample was separated by using $100 \mathrm{~m}$ column with $\mathrm{He}$ as a carrier gas. FAMEs were identified based on retention time observed, using Supelco standards obtained from Sigma-Aldrich (37 Component FAME Mix: Cat \# Number 200-838-9, St. Louis, MO, USA).

\subsection{Extraction of Bioactive Molecules and Estimation of Carotenoids}

The microalgae culture was cultivated at a scale of $500 \mathrm{~mL}$, using BG11 growth media. The strain was cultured at $30^{\circ} \mathrm{C}$, representing the low average annual temperature in Qatar and optimum temperature for best microalgal growth. The mixing was set to $150 \mathrm{rpm}$, under a photon flux density of $200 \mu \mathrm{mol}$ photons $\mathrm{m}^{-2} \mathrm{~s}^{-1}$, with continuous light, 24:00 (day and night cycle), using an illuminated shaker (Innova ${ }^{\circledR} 44 \mathrm{R}$ incubator shaker, New Brunswick Scientific, Ocala, FL, USA). Here, the only stress affecting the biomass was continuous light. The optical density of the culture was monitored at $750 \mathrm{~nm}$, and the culture was harvested at the late stationary phase. Algae secondary metabolites (carotenoids) were extracted via maceration, using hexane (analytical grade; Sigma-Aldrich, St. Louis, MO, USA) as an organic solvent [35]. For the extraction, $100 \mathrm{mg}$ of freeze-dried biomass was dissolved into $10 \mathrm{~mL}$ of hexane. The mixture was subjected to a $5 \mathrm{~min}$ treatment at $30 \mathrm{hz}$, using the TissueLyser II (Qiagen, \#85300, Valencia, CA, USA) for cell disruption. Then, the solvent fraction with the carotenoids was collected after centrifuge. The extraction was repeated on the same biomass, using fresh solvent, until the pellet became colorless. The total crude extract was subjected to spectral scan, at a range of wave lengths between 200 and 800 nm, using the Synergy H4 Hybrid Multi-Mode Microplate Reader (Bio-Tek, Winooski, VT, USA). The absorbance at $480 \mathrm{~nm}$ was recorded, and the concentration of carotenoids in the extract was calculated based on the following equation [36]:

$$
\text { Carotenoids }\left(\mathrm{ug} \mathrm{mL}^{-1}\right)=\text { Abs } 480 \mathrm{~nm} \times 4
$$

Further, the extract was dried, weighed, and dissolved in 1\% dimethylsulfoxide (DMSO), to a concentration of $100 \mathrm{mg} \mathrm{mL}^{-1}$. The crude extract was stored at $4{ }^{\circ} \mathrm{C}$, in the dark, prior to being used for the investigation of its antioxidant and antiproliferative capacities.

\subsection{TEAC Assay (Antioxidant Capacity)}

The Trolox Equivalent Antioxidant Capacity (TEAC) assay was performed by using the Sigma-Aldrich TEAC Kit (CS0790, St. Louis, MO, USA), in which a ferryl myoglobin radical is formed from metmyoglobin and hydrogen peroxide, which oxidizes the 2,2'-azino-bis (3-ethylbenzthiazoline-6-sulfonic acid) (ABTS), 
to produce ABTS+, a cation that is green in color and determined spectrophotometrically at $405 \mathrm{~nm}$, using Synergy H4 Hybrid Multi-Mode Microplate Reader (Bio-Tek, Winooski, VT, USA). A blank was prepared consisting of all the reagents except the algal extract to auto zero any absorbance caused by the reagents.The assay reflects the ABTS+ radical-scavenging capacity, in which a decrease in absorbance was observed due to the antioxidant molecules in the extract tested. All work was performed in the dark, at room temperature $[37,38]$.

\subsection{Cancer Cell Culture and Determination of the Antiproliferative Activity}

Human chronic myeloid leukemia K562 cells from ATCC were cultured in RPMI 1640 medium supplemented with $10 \%$ heat-inactivated fetal bovine serum (FBS), $100 \mathrm{IU} / \mathrm{mL}$ penicillin, $100 \mu \mathrm{g} \mathrm{mL}^{-1}$ streptomycin, and $2 \mathrm{mM}^{1-}$ glutamine. All the reagents were obtained from Sigma-Aldrich, St. Louis, $\mathrm{MO}$, USA. Cultures were maintained in a $\mathrm{CO}_{2}$ incubator (Thermo Fisher Scientific, Waltham, MA, USA,) at $37^{\circ} \mathrm{C}$. Cell viability was tested by using trypan blue dye exclusion method. The effects of Chlorella sp. QUCCCM3 extracts on proliferation of leukemia cancer cell line K562 CML (Chronic Myelogenous Leukemia) were determined by using colorimetric micro-culture assay with the 3-(4,5-dimethyl-2-thiazolyl)-2,5-diphenyl-2H tetrazolium bromide (MTT) as end point [39]. Antiproliferative activity was tested for a range of algal-extract concentrations of $(0,5,10,25,50,100$, 250 , and $500 \mu \mathrm{g} \mathrm{mL}^{-1}$ ), for an incubation period of $24 \mathrm{~h}$. An additional well was prepared as a blank, containing $1 \% \mathrm{DMSO}$, allowing a final concentration of $0.1 \%$. Such a concentration was previously described as safe for the cells [40]. Cell viability was measured through optical density, using a synergy H4 hybrid Multi-Mode Microplate Reader (Bio-Tek \# H4MLFPTAD, Winooski, VT, USA).

\subsection{Statistical Analysis}

Data were expressed as the mean of two independent parallel experiments. One-way ANOVA was used to assess the differences amongst the biomass productivities obtained after the different treatments and also between the inhibition \% of the leukemia cancer cells from K562, using the different concentrations of the Chlorella sp. QUCCCM3 crude extract. The standard error of mean values was calculated at $p<0.05$ level of significance.

\section{Results}

\subsection{Growth Performance and Thermotolerance Capacity of Chlorella sp. QUCCCM3 Isolate}

Chlorella sp. QUCCCM3 was cultivated under different temperatures, namely $30,35,40$, and $45^{\circ} \mathrm{C}$, knowing that $30^{\circ} \mathrm{C}$ corresponds to the annual average temperature, and $40{ }^{\circ} \mathrm{C}$ to the high annual average temperature, in Qatar. Chlorella sp. QUCCCM3 presented a high growth rate of $0.64 \pm 0.04 \mathrm{day}^{-1}$ and a biomass productivity of $0.132 \pm 0.01 \mathrm{~g} \mathrm{~L}^{-1}$ day $^{-1}$, as shown in Table 1 . Figure 1 showed that Chlorella sp. QUCCCM3's growth decreased slightly with a temperature increase up to $40^{\circ} \mathrm{C}$; however, it exhibited identical values of $\sim 0.54{ }^{\circ} \mathrm{C} \mathrm{day}^{-1}$ at 35 and $40{ }^{\circ} \mathrm{C}$. Similarly, the biomass productivity at $30^{\circ} \mathrm{C}$ was significantly higher $(p<0.5)$ than those recorded for the cultivation at 35 and $40^{\circ} \mathrm{C}$, showing similar biomass productivities of $0.118 \pm 0.02 \mathrm{~g} \mathrm{~L}^{-1}$ day $^{-1}$ and $0.111 \pm 0.01 \mathrm{~g} \mathrm{~L}^{-1} \mathrm{day}^{-1}$, respectively $(p>0.05)$, whereas no growth was recorded for the strain when cultivated at $45^{\circ} \mathrm{C}$. Our results proved that Chlorella sp. QUCCCM3 is a fast-growing strain that can adapt at high temperatures, up to $40^{\circ} \mathrm{C}$, corresponding to the high average temperature in Qatar. This confirms its thermotolerance capacity and therefore its suitability to be cultivated year-round, at a large scale, under Qatar's harsh climate. 
Table 1. Effect of temperature on growth parameters of the strain Chlorella sp. QUCCCM3. Number of replicates generating the mean, $n=2$.

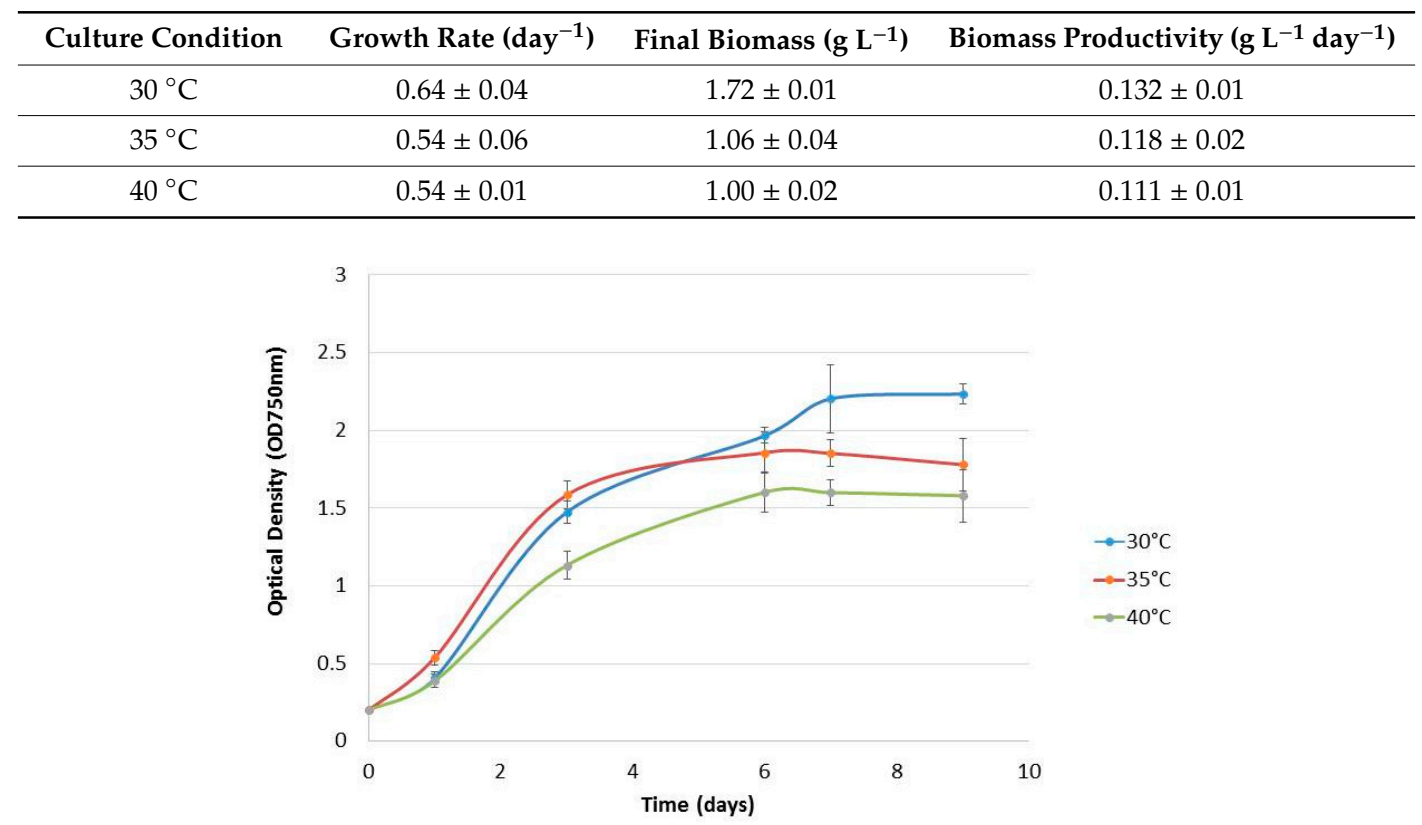

Figure 1. Growth curves of Chlorella sp. QUCCCM3 cultured under different temperatures. The points represent means $\pm \mathrm{SD}$ of samples, $n=2$.

\subsection{Biochemical Composition of the Chlorella sp. QUCCCM3}

An assessment of the metabolites content was performed for QUCCCM3, to investigate its nutritional potential. The biomass obtained at $30{ }^{\circ} \mathrm{C}$ was subjected to quantitative and qualitative metabolite analysis. Results showed that Chlorella sp. QUCCCM3 presented a high amount of proteins, reaching up to $43 \pm 2.3 \%$, whereas the lipid amount was found to be $33 \pm 1.75 \%$. Additionally, the carbohydrates estimated was up to $13.5 \pm 0.5 \%$, as illustrated in Figure 2. Such results highlight the potential of our local isolate as a novel source of proteins and lipids.

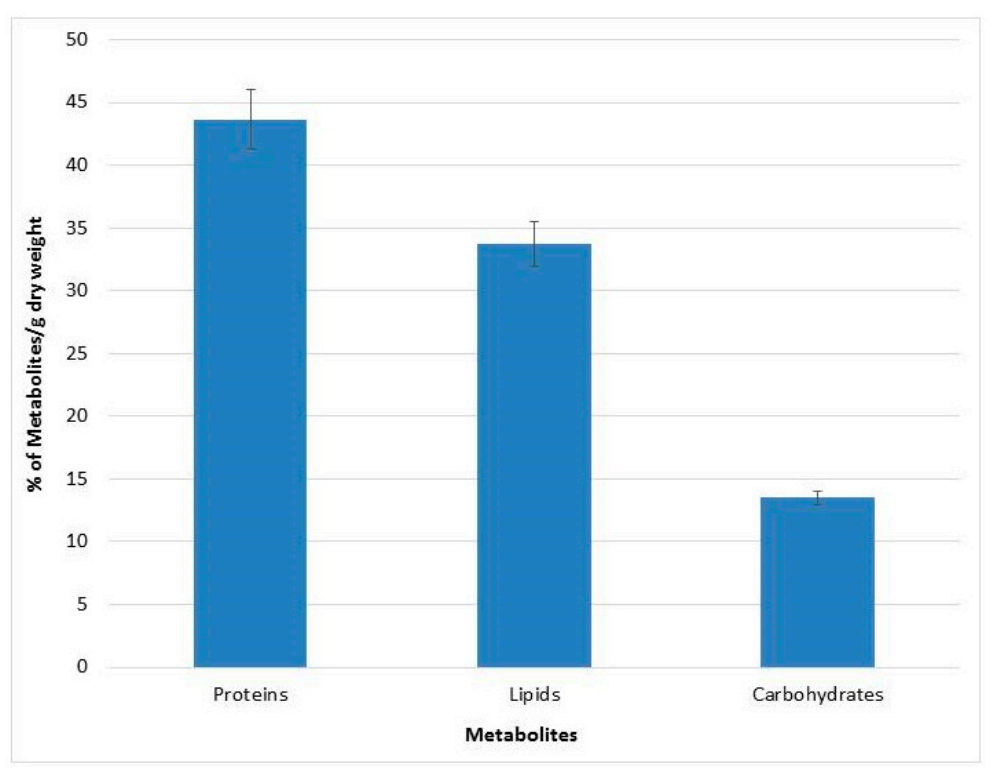

Figure 2. Metabolites characterization of Chlorella sp. QUCCCM3.

To support these findings, the quality of proteins in Chlorella sp. QUCCCM3 was analyzed through amino acid profiling. The obtained data are illustrated in Figure 3 and confirmed the presence of the 
nine essential amino acids with different concentrations. Glycine was the most abundant essential amino acid, accounting for almost $14 \%$ of total protein. It also showed the presence of $12 \%$ GLX (representing both glutamate and glutamine, glutamate being precursor to L-glutamic acid). Leucine was present in concentrations up to $8 \%$, and lysine, an important amino acid, was found to be $5 \%$ of the total proteins. The lowest concentrations of amino acids were found for histidine, tyrosine, tryptophan, and methionine.

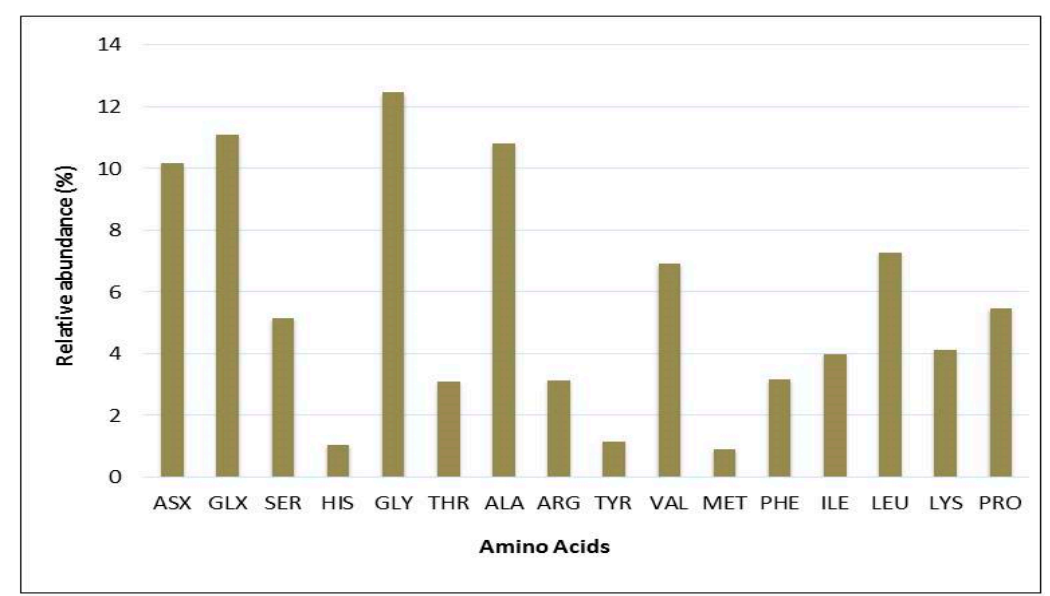

Figure 3. Percentages of total amino acid derivatives of Chlorella sp. QUCCCM3 protein lysate, obtained using the pre-column PITC labeling method, analyzed via HPLC-UV. ASX: Aspartic acid; GLX: Glutamic acid; SER: Serine; HIS: Histidine; GLY: Glycine; THR: Threonine; ALA: Alanine; ARG: Arginine; TYR: Tyrosine; VAL: Valine; MET: Methionine; PHE: Phenylalanine; ILE: Isoleucine; LEU: Leucine; LYS: Lysine; PRO: Proline.

In addition to the amino acids, the FAME profile of Chlorella sp. QUCCCM3 was also determined, and the results are presented in Table 2. It was observed that the unsaturated fatty acids responsible for enhancing the nutritional value of the biomass were contributing up to $20 \%$ of the total fatty acid content, with the presence of essential fatty acids such as omega-3 and omega- 6 . The omega-3 fatty acids identified were DHA and ALA, and the omega-6 fatty acids included Linoleic Acid (LA). The principal FAME among the saturated fatty acids was palmitic acid, with a content of $167 \pm 20.25 \mathrm{mg} \mathrm{g} \mathrm{dry} \mathrm{weight}^{-1}$ representing $35 \%$ of the total fatty acids.

Table 2. Fatty acid composition of Chlorella sp. QUCCCM3, a C. sp. isolate from Qatar, after cultivation in BG11 medium for 12 days at $30^{\circ} \mathrm{C}$. Profile obtained via GC-FID, using a trans-esterified sample.

\begin{tabular}{cc}
\hline FAME & FAME per $\mathbf{g}$ Dry Weight $\left(\mathbf{m g ~ g}^{\mathbf{- 1}}\right)$ \\
\hline Myristic acid C14:0 & $4.01 \pm 0.25$ \\
\hline Palmitic acid C16:0 & $167 \pm 20.25$ \\
\hline Stearic acid C18:0 & $7.8 \pm 3.7$ \\
\hline Elaidic acid C18:1 n9t & $16.17 \pm 1.5$ \\
\hline Oleic acid C18:1 n9c & $38.19 \pm 19.64$ \\
\hline Linoleic acid C18:2 n6c & $17.11 \pm 15.2$ \\
\hline Arachidic acid C20:0 & $94.56 \pm 93.5$ \\
\hline y-Linolenic acid C18:3n6 & $0.62 \pm 0.3$ \\
\hline Cis-11-Ecosenoic acid C20:1n9 & $4.29 \pm 3.82$ \\
\hline Cis-11,14-Eicosadienoic acid C20:2 & $2.03 \pm 0.91$ \\
\hline Behenic acid C22:0 & $2.38 \pm 0.302$ \\
\hline Lignoceric acid C24:0 & $0.74 \pm 0.03$ \\
\hline Docosahexaenoic acid C22:6n3 & $6.64 \pm 0.377$ \\
\hline
\end{tabular}




\subsection{Characterization of the Strain Cultivated under Different Stress Regimes}

Chlorella sp. QUCCCM3 showed a high growth rate and interesting biochemical profile, evidencing its suitability to be considered as a promising candidate for food supplement production. To further enhance its nutritional quality by increasing the amount of high-value added compounds associated with multiple health benefits, two different abiotic stressors, namely high temperature $\left(40^{\circ} \mathrm{C}\right)$ and continuous light, were applied separately. The comparative analysis of the cell morphologies when cultivated under both stresses, along with control condition, highlighted differences in the cell shape, size and, contents (Figure 4).
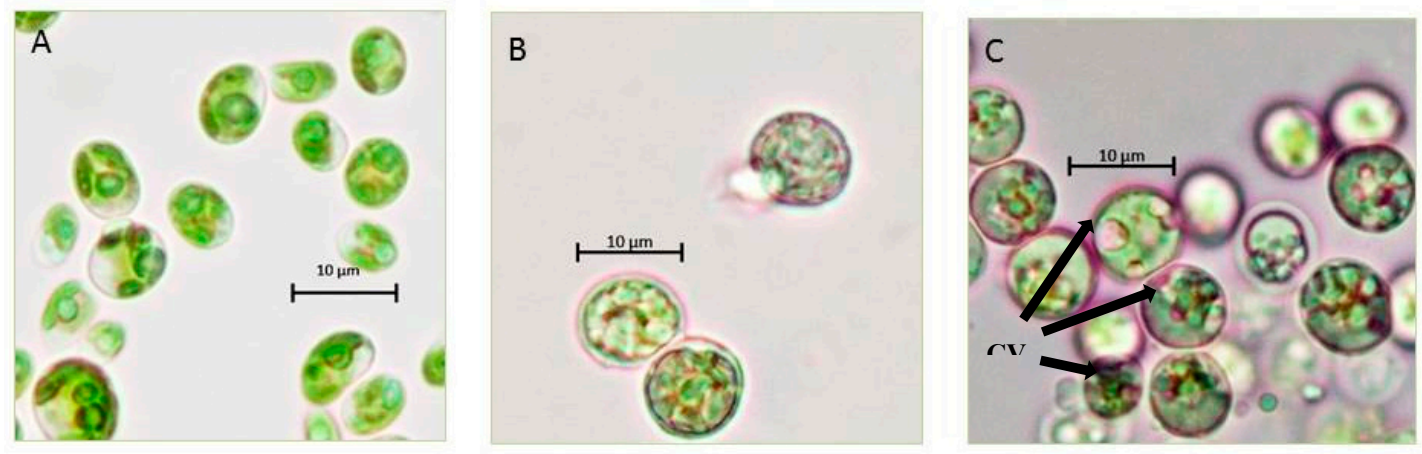

Figure 4. Morphological characterization of the Chlorella sp. QUCCCM3. Strains were cultivated under (A) control condition; (B) $40{ }^{\circ} \mathrm{C}$; and (C) continuous light at 100× magnification, using light microscopy (Primo star HAL microscope, full Kohler, Carl Zeiss, Germany); CV: carotenoids vesicle.

The cells cultivated under both stresses showed a spherical shape instead of the normal oval shape. Furthermore, the cells cultivated under $40^{\circ} \mathrm{C}$ presented a bigger size than the other previously cited conditions, whereas the microscopic observation of the cells cultivated under continuous light showed the presence of large orange vesicles. These vesicles correspond to the accumulation of carotenoids that are considered as high-value secondary metabolites. The existence of these carotenoids was confirmed by the presence of a peak of absorbance at $480 \mathrm{~nm}$, in a spectral scan analysis. The concentration of this pigment was estimated to be $0.5 \mathrm{mg} \mathrm{g}^{-1}$ dry weight.

\subsection{Antioxidant and Anticancer Potential of Chlorella sp. QUCCCM3}

The presence of the essential fatty acids and carotenoids, which are already known for their nutraceutical properties and antioxidant activity, led to the investigation of the potential health benefits of the Chlorella sp. QUCCCM3. Hence, antioxidant and anticancer activities of the cell extract were assessed. Results showed interesting antioxidant activity with $65.2 \pm 2.5 \mu \mathrm{mol} \mathrm{g}^{-1}$. In addition, the algal extract presented a high antiproliferative effect on the leukemia cancer cells K562, in a dose-dependent manner, as detected by MTT assay $(p<0.5)$. The hexane extract of Chlorella sp. QUCCCM3 showed an IC50 value of $21.37 \pm 2.98 \mu \mathrm{g} \mathrm{mL}^{-1}$ (Figure 5). Such interesting findings evidenced additional health benefits of our local microalgae strain and proved its suitability for anti-leukemia drug discovery. 


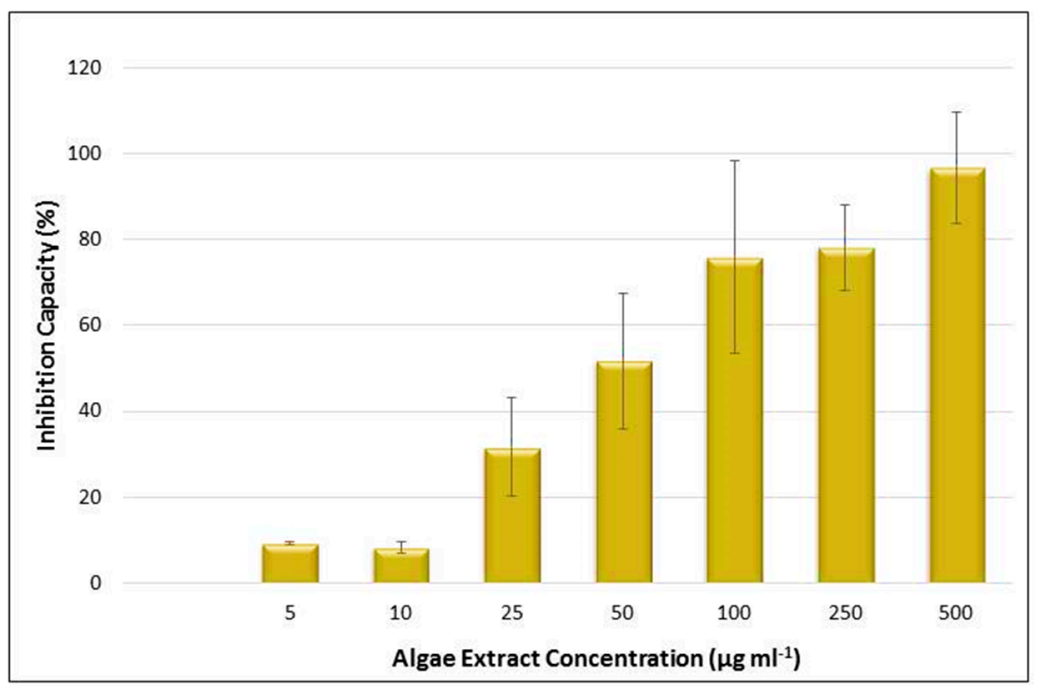

Figure 5. Inhibition capacity of the Chlorella sp. QUCCCM3 extract, using MTT assay against leukemia cancer cell line K562 after $24 \mathrm{~h}$ of incubation. Extracts used with concentrations of 5, 10, 25, 50, 100,250 , and $500 \mu \mathrm{g} \mathrm{mL} \mathrm{m}^{-1}$. Absorbance was measured at $540 \mathrm{~nm}$, using the automated Microplate Spectrophotometer (Biotek). The blank-corrected absorbance of the control wells was taken as 100\%, and the results were expressed as a percentage of the control. All data were recorded in triplicate, $n=3$.

\section{Discussion}

The growth rate obtained for Chlorella sp. QUCCCM3 isolated from the desert was similar to the growth compared to Chlorella sp. isolated from different environments, such as springs and mountains, at a temperature of $30{ }^{\circ} \mathrm{C}$, exhibiting a value of 0.66 day $^{-1}$ [24]. However, the local Chlorella sp. QUCCCM3 exhibited its thermotolerance capacity, being able to grow at $40{ }^{\circ} \mathrm{C}$, whereas the other Chlorella spp. were unable to survive even at $38^{\circ} \mathrm{C}$ [37]. It is known that temperature is one of the parameter influencing the algae growth, and previous data highlighted a correlation between increase in temperature and growth of microalgae, such that growth is optimum at $30^{\circ} \mathrm{C}[24,41]$. It was seen that majority of the work on Chlorella sp. has been limited up to $35^{\circ} \mathrm{C}$. According to a few researchers [42], the optimum temperature for Chlorella sp. is $30^{\circ} \mathrm{C}$, and at $35^{\circ} \mathrm{C}$, the growth is declining, whereas in our research, we found that, although the growth slightly decreased at $35^{\circ} \mathrm{C}$ (from 0.64 to 0.54 day $^{-1}$ ), Chlorella sp. QUCCCM3 was stable up to $40^{\circ} \mathrm{C}$, with negligible variations in growth. Therefore, the strain is considered thermotolerant, as it can grow in higher temperatures, as compared to other known Chlorella strains. Its tolerance can be attributed to its origin of isolation and its evolutionary adaptation to a desert climate over the years, making it unique. Our findings also showed best biomass productivity of $0.132 \pm 0.01 \mathrm{~g} \mathrm{~L}^{-1}$ at $30^{\circ} \mathrm{C}$ for Chlorella sp. QUCCCM3, which was higher than the productivity recorded for other Chlorella spp. $\left(0.114 \pm 0.850 \mathrm{~g} \mathrm{~L}^{-1}\right.$ day $\left.^{-1}\right)$, as reported by different researchers [43]. It should be noted that the growth characteristics of this strain can vary when another variable such as light intensity is tested along with temperature. Several researchers have proved that there exists a correlation between the effect of temperature and light on biomass production, such that maximum growth can be achieved under optimum light and temperature interactions $[44,45]$.

Microalgae are an important source for feed supplements and bioactives [46,47]. However, a key limiting factor in valorizing the microalgal biomass is its low productivity, which then reduces the economic feasibility of the biomass production for use as feed and nutraceuticals [48]. By presenting a high biomass productivity under normal growth conditions, Chlorella sp. QUCCCM3, demonstrated its capacity for high growth and biomass production under favorable cultivation conditions, thereby proving its commercial suitability. Chlorella sp. QUCCCM3 further exhibited a biomass concentration value of $1.72 \pm 0.01 \mathrm{~g} \mathrm{~L}^{-1}$, which slightly decreased at 35 and $40^{\circ} \mathrm{C}$, although the cells still expressed normal growth with the rise in temperature, which is remarkable. A similar trend was confirmed by several other studies on Chlorella sp. [49,50]. 
In addition to the biomass productivity, metabolite production is the other imperative factor toward commercial utilization of microalgae for nutritional purposes [51]. The protein content found for Chlorella sp. QUCCCM3, $43 \pm 2.3 \%$, was higher than commercially available Chlorella sp., having a value of $39.98 \%$ [52]. Protein quality is determined by the presence of essential amino acids. These amino acids greatly increase the value of the biomass, since animals cannot synthesize such amino acids, and their nutritional requirements for these molecules are met through their feed. Chlorella sp. QUCCCM3 was enriched with all the essential amino acids with the existence of Lysine up to $5 \%$, an important amino acid, indicating its suitability as potential feed. This amino acid also imparts a sweet flavor to the biomass, to improve the palatability for livestock, which is an important criterion for feed supplement production [53]. Similarly, in a different research study, it was proved that glutamate also contributes to flavor in the biomass. Chlorella sp. QUCCCM3 exhibited high amounts of glutamate, thus highlighting the sensory characteristics of the microalgae and improving the taste, when used as food ingredient [54].

In regard to the total lipids, the values reported for all Chlorella spp. ranged from 28 to 32\% [55]. Chlorella sp. QUCCCM3 exhibited a slightly higher amount of lipids when compared to the given range of values. Precisely, the lipid content in Chlorella sp. QUCCCM3 was found to be much higher when compared to the amounts observed for Chlorella pyrenoidosa and Chlorella vulgaris which presented values around $2 \%$ and $14-22 \%$, respectively [3]. The high amount of lipids was complemented by the presence of PUFAs, a key indicator for the nutritional potential of the strain. These long-chain fatty acids are known for their positive health benefits for animals and humans, including as antioxidants, anti-inflammatories, and anti-bacterial agents. The presence of DHA in the FAME profiling of Chlorella sp. QUCCCM3 biomass proved its commercial potential for producing feed for aquaculture [56]. It was stated that a microalgal diet enriched with DHA led to high growth rates of bivalve larvae, and its incorporation into poultry feed led to the production of omega-3-rich eggs [57,58]. Besides egg quality, dietary supplementation with 1-2\% of DHA-rich microalgae has shown to have a positive effect on serum composition, caracass trait, antioxidant status, and fatty acid deposition in broilers [59]. Furthermore, the other omega-3 fatty acid found, ALA, is primarily seen in products such as vegetable oils and cereals. It is known that ALA, when consumed, gets assimilated in the body, to form EPA, which is a very important omega-3 fatty acid with multiple health benefits. Chlorella sp. QUCCCM3 also possesses LA, which is observed in high amounts in corn oil, sunflower oil, walnuts, brazil nuts, and soya beans, and hence can be used to replace the oils and provide the same nutritional benefits, without causing the side effects, such as cardiovascular diseases. Palmitic acid found among the FAMEs is known to improve the quality of milk by regulating milk fats [9,12]. In this context, we can anticipate that Chlorella sp. QUCCCM3 has the potential to be used as feed for livestock production. A similar trend was seen for Rhodophytas, which also exhibited high palmitic acid content. However, the amount was lower than the values found in microalgae [60]. The Chlorella sp. QUCCCM3 isolate from Qatar showed slight variations in its FAME profile, as compared to strains found in Australia [52]. While the presence of the omega-3 fatty acid, ALA, was observed in microalgae isolated from both environments, DHA was only found in Chlorella sp. QUCCCM3. Our local microalgae strain exhibited an omega-6/omega-3 ratio of 0.42 , which is within the recommended range (0.25-1) for this strain to be beneficial also for human use [52]. The presence of important PUFAs (DHA and LA) showed that Chlorella sp. QUCCCM3 exhibits the cellular mechanisms for producing these compounds and thus can be modulated through variation of the cultivation regime $[51,61]$.

With regard to carbohydrate content of Chlorella sp. QUCCCM3, it was within the range that is commonly seen for microalgae [62].

Chlorella sp. QUCCCM3 was subjected to abiotic stress, to enhance its nutraceutical potential. Morphological differences, such as changes in cell size and shape, were observed under both stresses applied separately. The interesting observation that was made about the cell size at $40{ }^{\circ} \mathrm{C}$ can be explained by a phenomenon called gigantism that was previously described for Chlorella sp. under temperature stress [63]. Moreover, it is suggested that increase of the cell size occurs to regulate 
the internal temperature required for maintaining normal cell functionality at higher temperatures. Our assumption is that this feature can allow the exchange of fluids between cells by increasing membrane porosity, to maintain the ambient temperature required by the cells.

Chlorella sp. QUCCCM3 microalgae also exhibited large circular vesicles of carotenoids under continuous light stress, as seen in Figure 4. Such structures were not visible for Chlorella sp. QUCCCM3 when cultivated under normal conditions (control) and at $40^{\circ} \mathrm{C}$. It has been proved widely that light is a key factor influencing the production of carotenoids within the cells. The accumulation of these pigments can be attributed to photo-induced activation of gene-encoding enzymes involved in the $\beta$-carotene biosynthesis [64]. The presence of these high-value secondary metabolites indicated their possible high antioxidant potential. The antioxidant value for the extract of Chlorella sp. QUCCCM3 was found to be higher than the value reported in other research using different Chlorella sp., exhibiting $65.2 \pm 2.5 \mu \mathrm{mol} \mathrm{g}^{-1}$ and $56.09 \pm 1.99 \mu \mathrm{mol} \mathrm{g}^{-1}$, respectively [65], although both extractions were made in different solvents, with the former being hexane and the latter being water. In a different study, hexane extract for our strain exhibited very high antioxidant potential when compared to hexane fractions for a large number of Chlorella spp., as reported for Chlorella protothecoides $\left(3.49 \pm 0.13 \mu \mathrm{mol} \mathrm{g}^{-1}\right)$, Chlorella pyrenoidosa $\left(8.48 \pm 0.42 \mu \mathrm{mol} \mathrm{g}^{-1}\right)$, Chlorella vulgaris $\left(5.53 \pm 0.05 \mu \mathrm{mol} \mathrm{g}^{-1}\right)$, and Chlorella zofingiensis $\left(1.83 \pm 0.21 \mu \mathrm{mol} \mathrm{g}^{-1}\right)$ [66]. The pigments, coupled with important fatty acids such as DHA, found in our strain are a prerequisite for characterizing Chlorella sp. QUCCCM3 as a nutraceutical supplement. The health benefits of these molecules are well-known, specifically as anticancer molecules [67]. For this reason, the antiproliferative activity of Chlorella sp. QUCCCM3 crude extract was also carried out, and the results showed an interesting IC50 below the standard limit described by the American National Cancer Institute (IC50 $\leq 100 \mu \mathrm{g} \mathrm{mL}^{-1}$ ). It has been recommended that lower the IC50 value, the higher the potential of the molecules for drug development is. Furthermore, this activity is about half of that described previously for C. ellipsoidea and C. vulgaris extracts, showing IC50 of $40.73 \pm 3.71$ and $40.31 \pm 4.43 \mu \mathrm{g} \mathrm{mL}^{-1}$, respectively [68]. This interesting antiproliferative activity can be explained by the fact that Chlorella sp. QUCCCM3 is naturally adapted to produce secondary metabolites, such as carotenoids, to protect the cells when exposed to abiotic stressors common throughout the harsh Qatari climate. This also converges with other findings proving that microalgae, when under stress, developed components for survival and defence unique to them, in comparison to the terrestrial plants [69]. Chlorella sp. QUCCCM3 crude extract showed a peak of absorption at $480 \mathrm{~nm}$, indicating the presence of carotenoids [70].

\section{Conclusions}

Chlorella sp. QUCCCM3 demonstrated unique characteristics and can be considered for year-around cultivation due to its thermotolerance capacity. In addition, the presence of high protein content with essential amino acids with high amounts of glutamate and lysine confirmed its nutritional potential. PUFAs, such as DHA and carotenoids, found in the local strain serve as powerful antioxidants. Furthermore, the extracts from the strain also have significant anticancer activity against Leukemia cancer cells, making them interesting from a pharmaceutical perspective. Therefore, Chlorella sp. QUCCCM3 can be considered to be a promising alternative that has potential for sustainable food production in an arid environment.

Author Contributions: R.R., methodology, writing-original draft preparation, and investigation; I.S., conceptualization, investigation, writing-review and editing, and funding acquisition; T.B. and M.C., data curation and writing-review and editing; G.A.G., resources; H.A.J., project administration. All authors have read and agreed to the published version of the manuscript.

Funding: This report was made possible by the NPRP award (NPRP8-1087-1-207) from the Qatar National Research Fund (a member of The Qatar Foundation).

Acknowledgments: We thank the team members of the Centre for Sustainable Development, Qatar University, for their continued help. Special thanks go to Mariam Al Emadi for the financial support. The statements made herein are solely the responsibility of the authors. 
Conflicts of Interest: The authors declare no conflicts of interest. The funders had no role in the design of the study; in the collection, analyses, or interpretation of data; in the writing of the manuscript, or in the decision to publish the results.

\section{References}

1. Liu, X.; Clarens, A.F.; Colosi, L.M. Algae biodiesel has potential despite inconclusive results to date. Bioresour. Technol. 2012, 104, 803-806. [CrossRef] [PubMed]

2. Lardon, L.; Hélias, A.; Sialve, B.; Steyer, J.-P.; Bernard, O. Life-cycle assessment of biodiesel production from microalgae. Environ. Sci. Technol. 2009, 43, 6475-6481. [CrossRef] [PubMed]

3. Becker, E.W. Micro-algae as a source of protein. Biotechnol. Adv. 2007, 25, 207-210. [CrossRef] [PubMed]

4. Lee, Y.-K. Commercial production of microalgae in the Asia-Pacific rim. J. Appl. Phycol. 1997, 9, $403-411$. [CrossRef]

5. Muller-Feuga, A. The role of microalgae in aquaculture: Situation and trends. J. Appl. Phycol. 2000, 12, 527-534. [CrossRef]

6. Kovač Blagojević, D.; Simeunović, J.; Babić, O.; Mišan, A.; Milovanović, I. Algae in food and feed. Food Feed Res. 2013, 58226, 641.

7. Adarme-Vega, T.C.; Lim, D.K.Y.; Timmins, M.; Vernen, F.; Li, Y.; Schenk, P.M. Microalgal biofactories: A promising approach towards sustainable omega-3 fatty acid production. Microb. Cell Fact. 2012, 11, 96. [CrossRef]

8. Harel, M.; Clayton, D.; Bullis, R.A. Feed Formulation for Terrestral and Aquatic Animals. WO 2004/080196 A2, 23 September 2004.

9. Volkman, J.K.; Jeffrey, S.W.; Nichols, P.D.; Rogers, G.I.; Garland, C.D. Fatty acid and lipid composition of 10 species of microalgae used in mariculture. J. Exp. Mar. Biol. Ecol. 1989, 128, 219-240. [CrossRef]

10. Suh, S.-S.; Kim, S.J.; Hwang, J.; Park, M.; Lee, T.-K.; Kil, E.-J.; Lee, S. Fatty acid methyl ester profiles and nutritive values of 20 marine microalgae in Korea. Asian Pac. J. Trop. Med. 2015, 8, 191-196. [CrossRef]

11. Ryckebosch, E.; Bruneel, C.; Termote-Verhalle, R.; Goiris, K.; Muylaert, K.; Foubert, I. Nutritional evaluation of microalgae oils rich in omega-3 long chain polyunsaturated fatty acids as an alternative for fish oil. Food Chem. 2014, 160, 393-400. [CrossRef]

12. Wang, J.-L.; Dong, X.-Y.; Wei, F.; Zhong, J.; Liu, B.; Yao, M.-H.; Yang, M.; Zheng, C.; Quek, S.-Y.; Chen, H. Preparation and characterization of novel lipid carriers containing microalgae oil for food applications. J. Food Sci. 2014, 79, E169-E177. [CrossRef]

13. Gatenby, C.M.; Orcutt, D.M.; Kreeger, D.A.; Parker, B.C.; Jones, V.A.; Neves, R.J. Biochemical composition of three algal species proposed as food for captive freshwater mussels. J. Appl. Phycol. 2003, 15, 1-11. [CrossRef]

14. Norambuena, F.; Hermon, K.; Skrzypczyk, V.; Emery, J.; Sharon, Y.; Beard, A.; Turchini, G. Algae in fish feed: Performances and fatty acid metabolism in Juvenile Atlantic salmon. PLoS ONE 2015, 10, e0124042. [CrossRef]

15. Proksch, E.; Holleran, W.M.; Menon, G.K.; Elias, P.M.; Feingold, K.R. Barrier function regulates epidermal lipid and DNA synthesis. Br. J. Dermatol. 1993, 128, 473-482. [CrossRef] [PubMed]

16. Spolaore, P.; Joannis-Cassan, C.; Duran, E.; Isambert, A. Commercial applications of microalgae. J. Biosci. Bioeng. 2006, 101, 87-96. [CrossRef] [PubMed]

17. Ahmed, F.; Fanning, K.; Netzel, M.; Turner, W.; Li, Y.; Schenk, P.M. Profiling of carotenoids and antioxidant capacity of microalgae from subtropical coastal and brackish waters. Food Chem. 2014, 165, 300-306. [CrossRef]

18. Adarme-Vega, T.C.; Thomas-Hall, S.R.; Schenk, P.M. Towards sustainable sources for omega-3 fatty acids production. Curr. Opin. Biotechnol. 2014, 26, 14-18. [CrossRef] [PubMed]

19. Kotrbáček, V.; Doubek, J.; Doucha, J. The chlorococcalean alga Chlorella in animal nutrition: A review. J. Appl. Phycol. 2015, 27, 2173-2180. [CrossRef]

20. Saadaoui, I.; Al Emadi, M.; Bounnit, T.; Schipper, K.; Al Jabri, H. Cryopreservation of microalgae from desert environments of Qatar. J. Appl. Phycol. 2016, 28, 2233-2240. [CrossRef]

21. Stanier, R.Y.; Kunisawa, R.; Mandel, M.; Cohen-Bazire, G. Purification and properties of unicellular blue-green algae (order Chroococcales). Bacteriol. Rev. 1971, 35, 171-205. [CrossRef] 
22. Deng, X.; Chen, B.; Xue, C.; Li, D.; Hu, X.; Gao, K. Biomass production and biochemical profiles of a freshwater microalga Chlorella kessleri in mixotrophic culture: Effects of light intensity and photoperiodicity. Bioresour. Technol. 2019, 273, 358-367. [CrossRef] [PubMed]

23. Zhu, C.J.; Lee, Y.K. Determination of biomass dry weight of marine microalgae. J. Appl. Phycol. 1997, 9, 189-194. [CrossRef]

24. Aleya, L.; Dauta, A.; Reynolds, C.S. Endogenous regulation of the growth-rate responses of a spring-dwelling strain of the freshwater alga, Chlorella minutissima, to light and temperature. Eur. J. Protistol. 2011, 47, 239-244. [CrossRef] [PubMed]

25. Hempel, N.; Petrick, I.; Behrendt, F. Biomass productivity and productivity of fatty acids and amino acids of microalgae strains as key characteristics of suitability for biodiesel production. J. Appl. Phycol. 2012, 24, 1407-1418. [CrossRef]

26. Barbarino, E.; Lourenço, S.O. An evaluation of methods for extraction and quantification of protein from marine macro- and microalgae. J. Appl. Phycol. 2005, 17, 447-460. [CrossRef]

27. Lowry, O.H.; Rosebrough, N.J.; Farr, A.L.; Randall, R.J. Protein measurement with the Folin phenol reagent. J. Biol. Chem. 1951, 193, 265-275.

28. Folch, J.; Lees, M.; Sloane Stanley, G.H. A simple method for the isolation and purification of total lipides from animal tissues. J. Biol. Chem. 1957, 226, 497-509.

29. Saadaoui, I.; Al Ghazal, G.; Bounnit, T.; Al Khulaifi, F.; Al Jabri, H.; Potts, M. Evidence of thermo and halotolerant Nannochloris isolate suitable for biodiesel production in Qatar Culture Collection of Cyanobacteria and Microalgae. Algal Res. 2016, 14, 39-47. [CrossRef]

30. Arora, N.; Patel, A.; Pruthi, P.A.; Pruthi, V. Synergistic dynamics of nitrogen and phosphorous influences lipid productivity in Chlorella minutissima for biodiesel production. Bioresour. Technol. 2016, 213, 79-87. [CrossRef]

31. Dubois, M.; Gilles, K.A.; Ton, J.K.H.; Rebers, P.A.; Smith, F. Colorimetric method for determination of sugars and related substances. Anal. Chem. 1956, 28, 350-356. [CrossRef]

32. Blankenship, D.T.; Krivanek, M.A.; Ackermann, B.L.; Cardin, A.D. High-sensitivity amino acid analysis by derivatization with o-phthalaldehyde and 9-fluorenylmethyl chloroformate using fluorescence detection: Applications in protein structure determination. Anal. Biochem. 1989, 178, 227-232. [CrossRef]

33. Gehrke, C.W.; Wall, L.L.; Absheer, J.S. Sample preparation for chromatography of amino acids: Acid hydrolysis of proteins. J. Assoc. Off. Anal. Chem. 1985, 68, 811-821. [CrossRef]

34. Zheng, N.; Xiao, H.; Zhang, Z.; Gao, X.; Zhao, J. Rapid and sensitive method for determining free amino acids in plant tissue by high-performance liquid chromatography with fluorescence detection. Acta Geochim. 2017, 36, 680-696. [CrossRef]

35. Poojary, M.M.; Barba, F.J.; Aliakbarian, B.; Donsi, F.; Pataro, G.; Dias, D.A.; Juliano, P. Innovative alternative technologies to extract carotenoids from microalgae and seaweeds. Mar. Drugs 2016, 14, 214. [CrossRef]

36. Xu, Y.; Ibrahim, I.M.; Harvey, P.J. The influence of photoperiod and light intensity on the growth and photosynthesis of Dunaliella salina (chlorophyta) CCAP 19/30. Plant Physiol. Biochem. 2016, 106, 305-315. [CrossRef]

37. Sheih, I.-C.; Wu, T.-K.; Fang, T. Antioxidant properties of a new antioxidative peptide from algae protein hydrolysate in different oxidation systems. Bioresour. Technol. 2009, 100, 3419-3425. [CrossRef] [PubMed]

38. Saadaoui, I.; Sedky, R.; Rasheed, R.; Bounnit, T.; Almahmoud, A.; Elshekh, A.; Dalgamouni, T.; al Jmal, K.; Das, P.; Al Jabri, H. Assessment of the algae-based biofertilizer influence on date palm (Phoenix dactylifera L.) cultivation. J. Appl. Phycol. 2019, 31, 457-463. [CrossRef]

39. Mosmann, T. Rapid colorimetric assay for cellular growth and survival: Application to proliferation and cytotoxicity assays. J. Immunol. Methods 1983, 65, 55-63. [CrossRef]

40. Raghavan, R.; Cheriyamundath, S.; Madassery, J. Dimethyl sulfoxide inactivates the anticancer effect of cisplatin against human myelogenous leukemia cell lines in in vitro assays. Indian J. Pharmacol. 2015, 47, 322-324.

41. Butterwick, C.; Heaney, S.I.; Talling, J.F. Diversity in the influence of temperature on the growth rates of freshwater algae, and its ecological relevance. Freshw. Biol. 2005, 50, 291-300. [CrossRef]

42. Carlsson, A.S.; van Beilen, J.B.; Möller, R.; Clayton, D. Micro- and Macro-Algae: Utility for Industrial Applications; CPL Press: Newbury, UK, 2007; ISBN 9781872691299. 
43. Wong, Y. Growth medium screening for chlorella vulgaris growth and lipid production. J. Aquac. Mar. Biol. 2017, 6, 1-10. [CrossRef]

44. Ota, M.; Takenaka, M.; Sato, Y.; Lee Smith, R.; Inomata, H. Effects of light intensity and temperature on photoautotrophic growth of a green microalga, Chlorococcum littorale. Biotechnol. Rep. 2015, 7, $24-29$. [CrossRef] [PubMed]

45. Bouterfas, R.; Belkoura, M.; Dauta, A. Light and temperature effects on the growth rate of three freshwater algae isolated from a eutrophic lake. Hydrobiologia 2002, 489, 207-217. [CrossRef]

46. Lee, S.H.; Kang, H.J.; Lee, H.-J.; Kang, M.-H.; Park, Y.K. Six-week supplementation with Chlorella has favorable impact on antioxidant status in Korean male smokers. Nutrition 2010, 26, 175-183. [CrossRef] [PubMed]

47. Saadaoui, I.; Rasheed, R.; Abdulrahman, N.; Bounnit, T.; Cherif, M.; Al Jabri, H.; Mraiche, F. Algae-derived bioactive compounds with anti-lung cancer potential. Mar. Drugs 2020, 18, 197. [CrossRef]

48. Fu, W.; Gudmundsson, O.; Feist, A.M.; Herjolfsson, G.; Brynjolfsson, S.; Palsson, B.Ø. Maximizing biomass productivity and cell density of Chlorella vulgaris by using light-emitting diode-based photobioreactor. J. Biotechnol. 2012, 161, 242-249. [CrossRef]

49. Barghbani, R.; Rezaei, K.; Javanshir, A. Investigating the effects of several parameters on the growth of chlorella vulgaris using Taguchi's experimental approach. Int. J. Biotechnol. Wellness Ind. 2012, 1, 128-133.

50. Dvoretsky, D.; Dvoretsky, S.; Peshkova, E.; Temnov, M. Optimization of the process of cultivation of microalgae chlorella vulgaris biomass with high lipid content for biofuel production. Chem. Eng. Trans. 2015, 43, 361-366.

51. Lim, D.K.Y.; Garg, S.; Timmins, M.; Zhang, E.S.B.; Thomas-Hall, S.R.; Schuhmann, H.; Li, Y.; Schenk, P.M. Isolation and evaluation of oil-producing microalgae from subtropical coastal and Brackish waters. PLOS ONE 2012, 7, e40751. [CrossRef]

52. Kent, M.; Welladsen, H.; Mangott, A.; Li, Y. Nutritional evaluation of Australian microalgae as potential human health supplements. PLoS ONE 2015, 10, e0118985. [CrossRef]

53. Hani, N.; Ching, C. Nutritional composition of edible seaweed Gracilaria changgi. Food Chem. 2000, 68, 69-76.

54. Rioux, L.E.; Beaulieu, L.; Turgeon, S.L. Seaweeds: A traditional ingredients for new gastronomic sensation. Food Hydrocoll. 2017, 68, 255-265. [CrossRef]

55. Yusuf, C. Biodiesel from microalgae. Biotechnol. Adv. 2007, 25, 294-306.

56. Chauton, M.S.; Reitan, K.I.; Norsker, N.H.; Tveterås, R.; Kleivdal, H.T. A techno-economic analysis of industrial production of marine microalgae as a source of EPA and DHA-rich raw material for aquafeed: Research challenges and possibilities. Aquaculture 2015, 436, 95-103. [CrossRef]

57. Chu, F.-L.E.; Webb, K.L. Polyunsaturated fatty acids and neutral lipids in developing larvae of the oyster, Crassostrea virginica. Lipids 1984, 19, 815. [CrossRef]

58. Brown, M.R. The amino-acid and sugar composition of 16 species of microalgae used in mariculture. J. Exp. Mar. Biol. Ecol. 1991, 145, 79-99. [CrossRef]

59. Long, S.F.; Kang, S.; Wang, Q.Q.; Xu, Y.T.; Pan, L.; Hu, J.X.; Li, M.; Piao, X.S. Dietary supplementation with DHA-rich microalgae improves performance, serum composition, carcass trait, antioxidant status, and fatty acid profile of broilers. Poult. Sci. 2018, 97, 1881-1890. [CrossRef]

60. Gressler, V.; Yokoya, N.S.; Fujii, M.T.; Colepicolo, P.; Filho, J.M.; Torres, R.P.; Pinto, E. Lipid, fatty acid, protein, amino acid and ash contents in four Brazilian red algae species. Food Chem. 2010, 120, 585-590. [CrossRef]

61. Sharma, K.; Schuhmann, H.; Schenk, P. High lipid induction in microalgae for biodiesel production. Energies 2012, 5, 1532-1553. [CrossRef]

62. Brown, M.R.; Jeffrey, S.W.; Volkman, J.K.; Dunstan, G.A. Nutritional properties of microalgae for mariculture. Aquaculture 1997, 151, 315-331. [CrossRef]

63. Lorenzen, H. Temperatureinflüsse auf Chlorella pyrenoidosa unter besonderer Berücksichtigung der Zellentwicklung. Flora Allg. Bot. Ztg. 1963, 153, 554-592. [CrossRef]

64. Huang, J.J.; Lin, S.; Xu, W.; Cheung, P.C.K. Occurrence and biosynthesis of carotenoids in phytoplankton. Biotechnol. Adv. 2017, 35, 597-618. [CrossRef] [PubMed]

65. Wu, L.; Ho, J.A.; Shieh, M.-C.; Lu, I.-W. Antioxidant and antiproliferative activities of spirulina and chlorella water extracts. J. Agric. Food Chem. 2005, 53, 4207-4212. [CrossRef] 
66. Li, H.B.; Cheng, K.W.; Wong, C.C.; Fan, K.W.; Chen, F.; Jiang, Y. Evaluation of antioxidant capacity and total phenolic content of different fractions of selected microalgae. Food Chem. 2007, 102, 771-776. [CrossRef]

67. Sathasivam, R.; Ki, J.-S. A review of the biological activities of microalgal carotenoids and their potential use in healthcare and cosmetic industries. Mar. Drugs 2018, 16, 26. [CrossRef]

68. Cha, K.H.; Koo, S.Y.; Lee, D.-U. Antiproliferative effects of carotenoids extracted from chlorella ellipsoidea and chlorella vulgaris on human colon cancer cells. J. Agric. Food Chem. 2008, 56, 10521-10526. [CrossRef]

69. Lauritano, C.; Andersen, J.H.; Hansen, E.; Albrigtsen, M.; Escalera, L.; Esposito, F.; Helland, K.; Hanssen, K.; Romano, G.; Ianora, A. Bioactivity screening of microalgae for antioxidant, anti-inflammatory, anticancer, anti-diabetes, and antibacterial activities. Front. Mar. Sci. 2016, 3, 1-2. [CrossRef]

70. Ponesakki, G.; Noda, K.; Manabe, Y.; Ohkubo, T.; Tanaka, Y.; Maoka, T.; Sugawara, T.; Hirata, T. Siphonaxanthin, a marine carotenoid from green algae, effectively induces apoptosis in human leukemia (HL-60) cells. Biochim. Biophys. Acta 2011, 1810, 497-503.

(C) 2020 by the authors. Licensee MDPI, Basel, Switzerland. This article is an open access article distributed under the terms and conditions of the Creative Commons Attribution (CC BY) license (http://creativecommons.org/licenses/by/4.0/). 